\title{
PNEUMATIKUS IZOM VÉGRAHAJTÓK VIZSGÁLATÁRA ALKALMAS KÍSÉRLETI BERENDEZÉS TESZTELÉSE
}

\author{
Sárosi József - Csikós Sándor
}

\begin{abstract}
Absztrakt: Megnőtt napjainkban az érdeklődés az úgynevezett kontrakciós - dugattyú nélküli pneumatikus munkahengerek iránt. E pneumatikus végrehajtók a klasszikus, ipari környezetben fellelhető alkalmazásokon (pl. lyukasztógép, papír- és fóliatekercselő, emelőszerkezet, illetve vibrációs tölcsér) túl egyre fontosabb szerepet játszanak az orvostudomány (pl. múvégtag mozgatása), valamint a robotika (pl. ugráló és sétáló robotok) területén is. E cikkünkben egy olyan kísérleti berendezést tesztelünk, melyet az ilyen végrehajtók legfontosabb jellemzőinek meghatározására fejlesztettünk ki.

Abstract: Lately, interest has increased in the so called contracting - pistonless - pneumatic cylinders. These pneumatic actuators play an important role in industry applications (e.g. hole punchers, winders, lifting mechanisms, vibrating funnels) but also in the fields of medicine (e.g. moving artificial limbs) and robotics (e.g. jumping and bipedal robots). In this paper an experimental setup is shown which has been developed to investigate the most important characteristics of these pneumatic actuators.
\end{abstract}

Kulcsszavak: pneumatikus mesterséges izom, Fluidic Muscle, tesztberendezés, erő-kontrakció jelleggörbék

Keywords: pneumatic artificial muscle, Fluidic Muscle, experimental setup, force-contraction characteristics

\section{Bevezetés}

A sủrített levegővel működő végrehajtók (aktuátorok) közül a legkevésbé ismert az összehúzódáson alapuló, ún. kontrakciós pneumatikus munkahenger, amit szokás pneumatikus mesterséges izomnak (PMI), ill. pneumatikus izom végrehajtónak is nevezni. A nemzetközi irodalmakban további elnevezéseket (pl. Pneumatic Muscle Actuator, Fluid Actuator, Fluid-Driven Tension Actuator, Axially Contractible Actuator, Tension Actuator) is találunk (Daerden-Lefeber, 2002; Ramasary et al., 2005). E végrehajtók hátrányait Sárosi et al. (2015a) foglalja össze. Az 1. ábra egy PMI általános felépítését szemlélteti.

\section{1. ábra: A pneumatikus mesterséges izom felépítése}

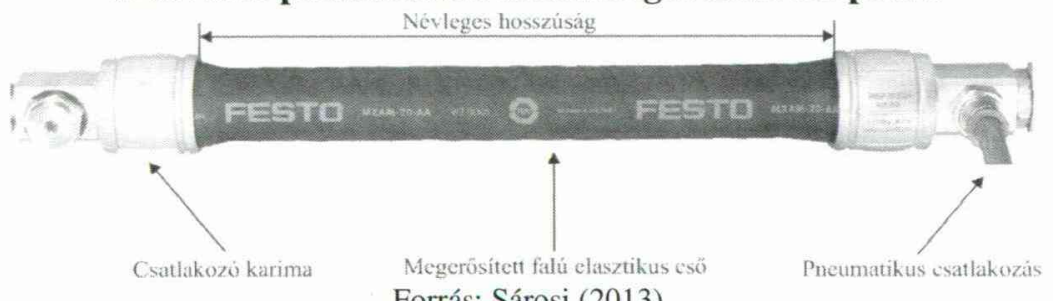

Forrás: Sárosi (2013)

A PMI-k csoportosíthatók a rugalmas cső és az ezt megerősítő, ún. teherviselő szálak kapcsolata alapján. Amíg a fonott és hálós izmoknál a rugalmas csövet 
kívülről veszik körbe a megerősítő fonatok, addig a beágyazott izmok esetében a teherviselő szálak a rugalmas csőbe kerülnek beágyazásra (2. ábra). 2. ábra: A fonott (balra) és beágyazott (jobbra) izom szerkezeti felépítése

(pl.: nejlon, aramid, üvegszál) latex, szilikongumi

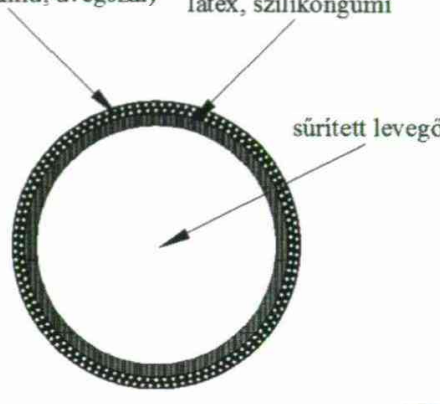

spirál fonat

(aramid)

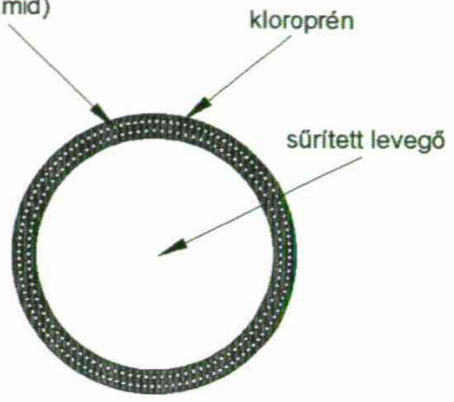

\section{0}

Forrás: Sárosi (2013)

E munkánkhoz különbözö, Festo által szabadalmaztatott és gyártott, Fluidic Muscle elnevezésủ, beágyazott típusú PMI-t használunk az általunk kifejlesztett kísérleti berendezés tesztelésére.

\section{PMI-k vizsgálatára alkalmas kísérleti berendezés és beállítások}

A pneumatikus mesterséges izmok alapvető tulajdonságainak meghatározásához szükség van egy olyan kísérleti berendezésre, mely képes az izom által kifejtett erő, a pozíció (lineáris elmozdulás) és a nyomás mérésére (3. ábra) (Sárosi, 2013).

\section{3. ábra: Kísérleti berendezés a PMI-k vizsgálatára}

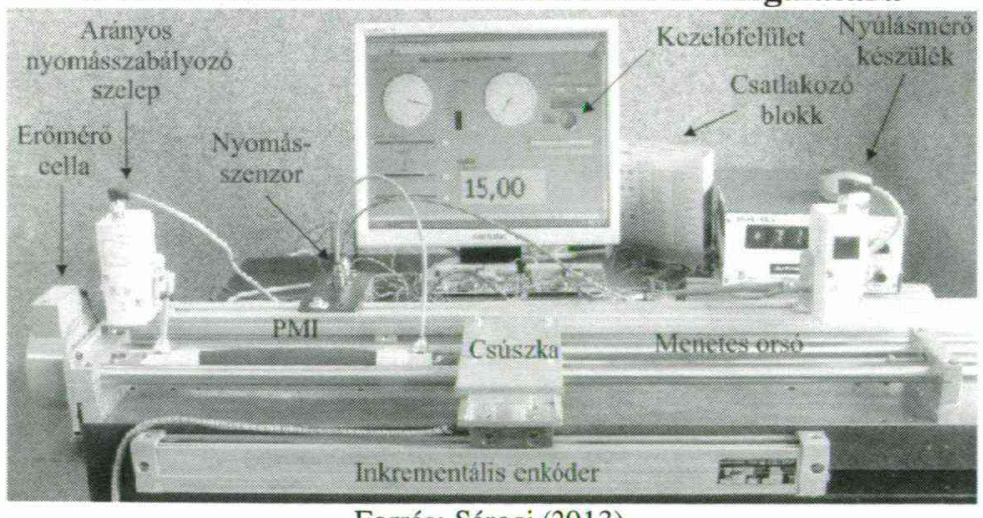

Forrás: Sárosi (2013)

A 3. ábrán látható berendezéssel számos statikus és dinamikus vizsgálat hajtható végre, melyek közül a legfontosabb kerülnek ismertetésre. 
A 4. ábrán állandó terhelés ( $\mathrm{m}=$ áll.) és nyomás $(\mathrm{p}=$ áll.) esetén bekövetkező változások követhetők nyomon. Állandó terhelés esetén, ha a nyomást növeljük ( $\mathrm{p}_{0}$ $\left.<\mathrm{p}_{1}<\mathrm{p}_{2}\right)$, akkor a térfogat növekszik $\left(\mathrm{V}_{0}<\mathrm{V}_{1}<\mathrm{V}_{2}\right)$ és a PMI rövidülni fog. Állandó nyomás esetén a PMI szintén rövidülni fog, ha a terhelés csökken $\left(\mathrm{m}_{1}>\mathrm{m}_{2}\right.$ $\left.>\mathrm{m}_{3}\right)$, maximális összehúzódáskor a PMI térfogata maximálissá $\left(\mathrm{V}_{\max }\right)$, míg az erő nullává $(\mathrm{m}=0, \mathrm{~F}=0)$ válik. Az 5. ábra a PMI függőleges elrendezése esetén szemlélteti ezeket.

\section{4. ábra: Mérési elrendezés állandó terhelés és nyomás esetén}

Allandó terhelés ( $m$ - áll.)

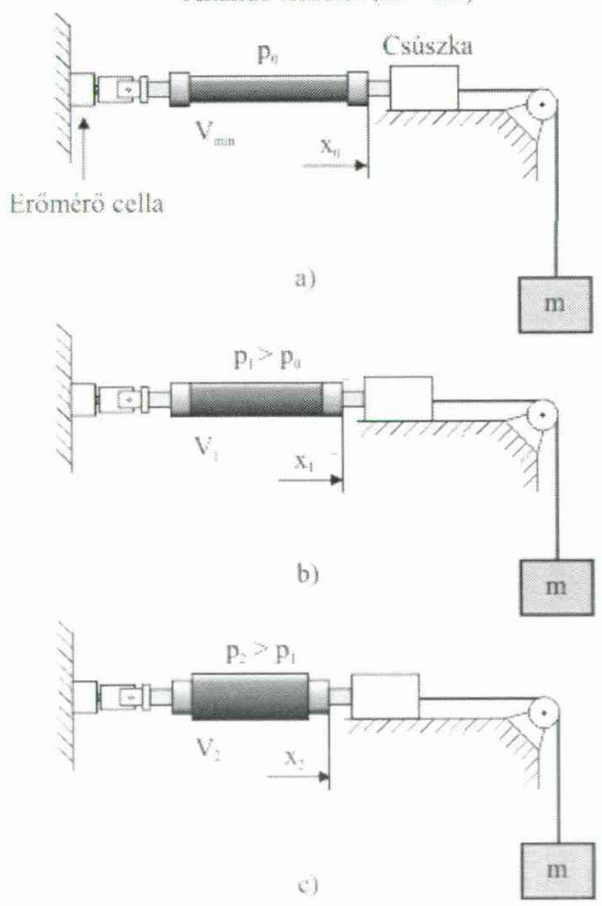

Állandó nyomás $(\mathrm{p}-$ åll. $)$
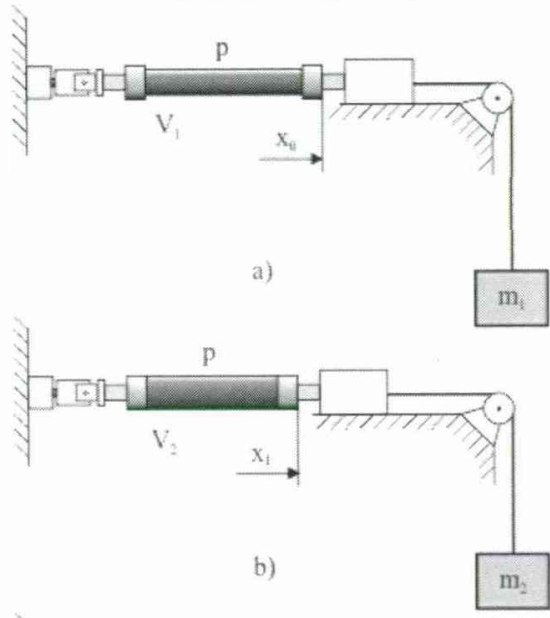

$m_{2}<m$

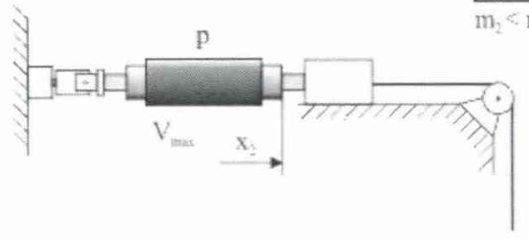

c)

Forrás: Sárosi (2013) 
5. ábra: A PMI viselkedése állandó terhelés és nyomás alkalmazásával

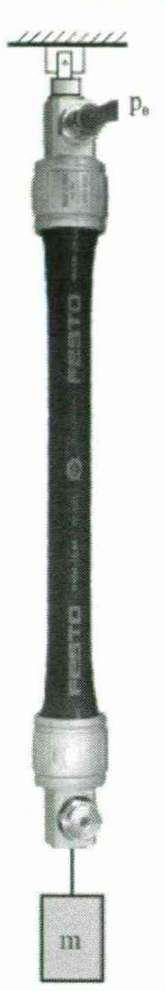

a)

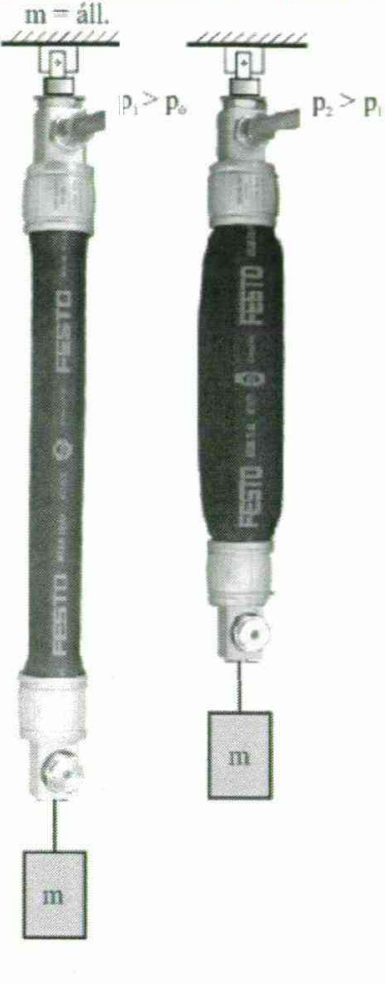

b)

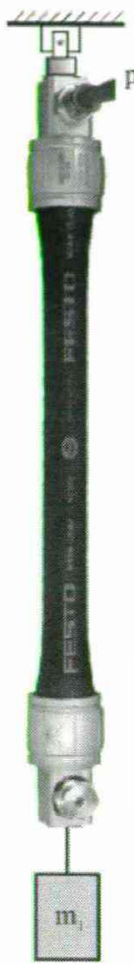

a)

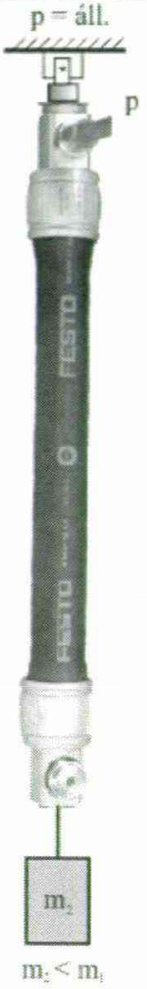

b)

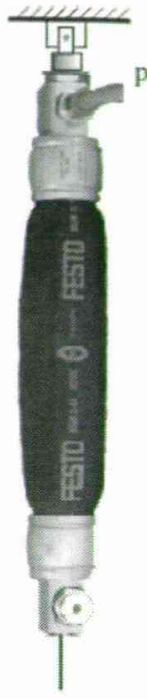

$m-0$

c)

Forrás: Sárosi (2013)

A 6. ábrán bemutatott elrendezéssel egyrészt az állandó, rögzített pozíció mellett változó nyomás esetén kialakuló erő mérhető, valamint az izom-rugó pár antagonisztikus vizsgálata végezhető el. Ez utóbbi azért is fontos, mert a PMI-k alapvetően csak egyirányú mozgásra (összehúzódásra) képesek, így pl. egy másik izom vagy egy rugó szükséges a kétirányú mozgás megvalósításához (Balara, 2013; Pitel et al., 2014). 


\section{6. ábra: Mérési elrendezés állandó pozíció, valamint izom-rugó pár esetén \\ Allandó pozició $(x-$ áll. $)$ \\ Izom-rugó elrendezés}

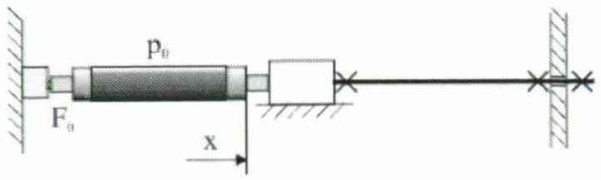

a)

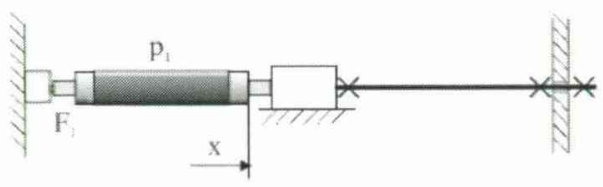

b)

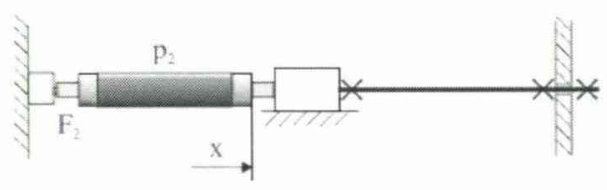

c)

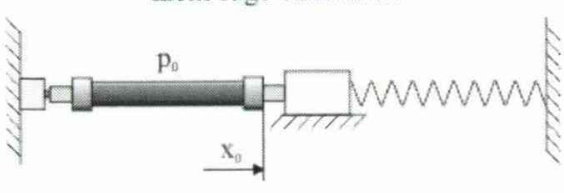

a)

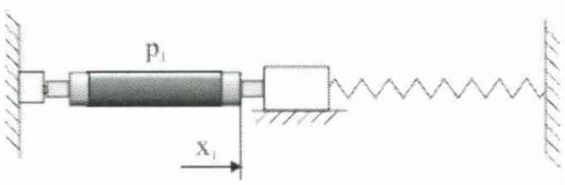

b)

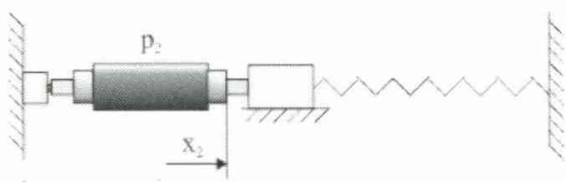

c)

Forrás: Sárosi (2013)

A PMI alkalmazása szempontjából a legnagyobb jelentőséggel az állandó nyomáson történő működtetés bír, ezért a kísérleti berendezés e beállítását teszteltük különböző átméröjủ és hosszúságú izmokkal. Az izmok vízszintes elrendezésben kerültek beépítésre a tesztberendezésbe úgy, hogy az egyik végét rögzítettuik az erőmérő cellához, míg a másik vége elmozdulhatott. A 3. ábrán látható megoldást követtük, vagyis a mozdulni képes oldalhoz nem különbözö terheléseket, hanem egy menetes orsót rögzítettünk annak érdekében, hogy tetszőlegesen tudjuk változtatni a pozíciót. Valamennyi mérést ötszöri ismétléssel végeztünk és az eredményeket átlagoltuk.

A laboratóriumi vizsgálathoz felhasznált Fluidic Muscle-ok esetében a következő jelöléseket alkalmazzuk (Festo, 2015):

- DMSP: gyárilag szerelt változat,

- MAS: szerelhető változat,

- átmérö [mm]: 5, 10, 20 és 40,

- hosszúság [mm]: átmérőtől függően 30-1000, ill. 40/60/120-9000,

- csatlakozási módok: RM - radiális, AM - axiális és CM - csatlakozás nélküli.

Ez alapján pl. a DMSP-20-200N-RM-RM kód egy olyan gyárilag szerelt izmot jelent, mely $20 \mathrm{~mm}$ átmérőjü, $200 \mathrm{~mm}$ hosszúságú és mindkét végén radiális csatlakozással rendelkezik. 


\section{Mérési eredmények}

A PMI-k legfontosabb karakterisztikájának a statikus erő-kontrakció (erő-relatív elmozdulás) függvénykapcsolat tekinthető konstans nyomásokon. Az általuk kifejthető erő maximális értéke a névleges hosszúság külső erővel történő megnövelésével érhető el, míg minimális értéke $(\mathrm{F}=0 \mathrm{~N})$ a kontrakciómaximumnál (minimális hosszúságnál) lép fel (7. ábra).

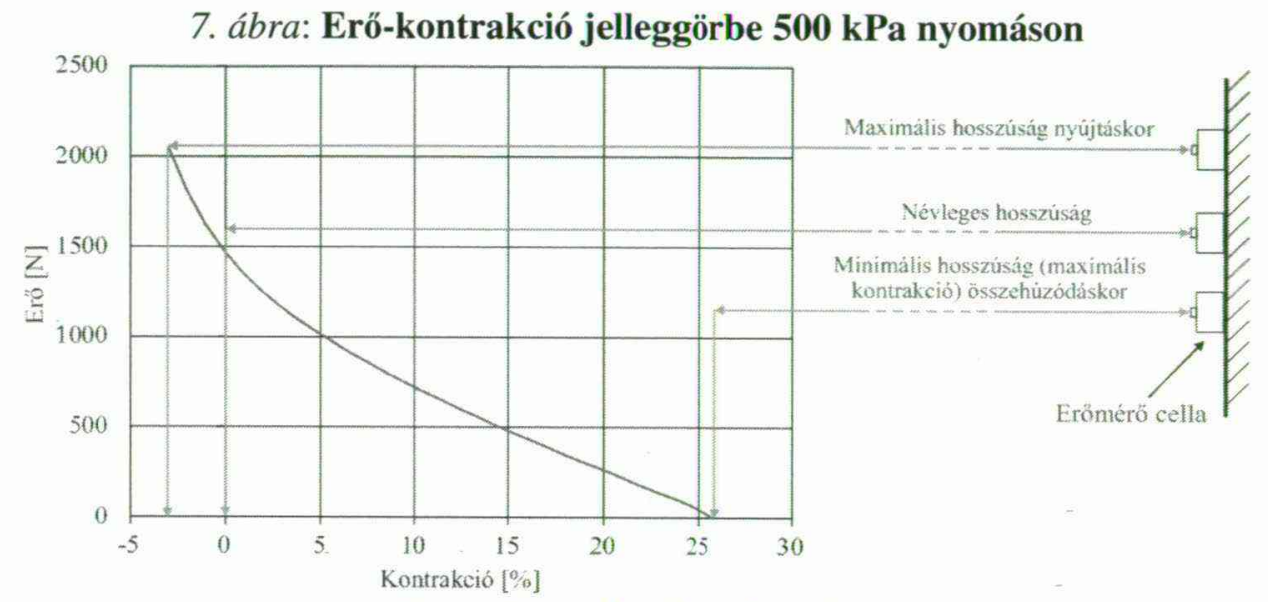

Forrás: A szerzők saját szerkesztése.

A 3. ábrán ismertetett berendezés részletes tesztelését öt darab izommal végeztük, melyek erö-kontrakció jelleggörbéit - 0-500 kPa nyomástartományban $100 \mathrm{kPa}$-onként - a 8. ábra mutatja az alábbi sorrendnek megfelelően (balról jobbra):

- DMSP-10-100N-RM-RM,

- DMSP-10-250N-RM-RM,

- DMSP-20-200N-RM-RM,

- DMSP-20-400N-RM-RM,

- DMSP-40-200N-RM-RM. 


\section{8. ábra: A PMI-k erö-kontrakció jelleggörbéi}
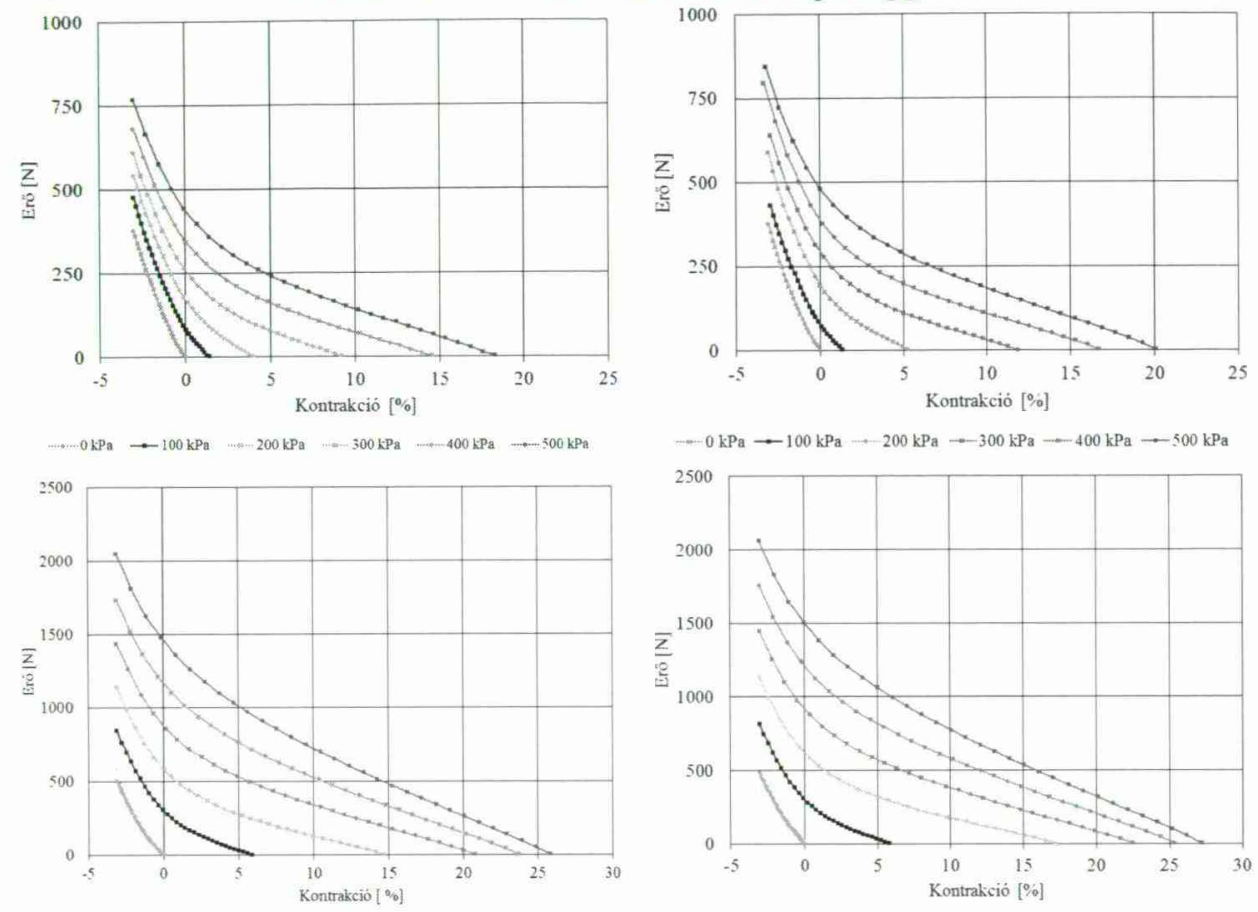

$+0 \mathrm{KPa} \rightarrow 100 \mathrm{kPa}-200 \mathrm{kPa} \rightarrow 300 \mathrm{kPa} \rightarrow 400 \mathrm{kPa} \rightarrow 500 \mathrm{kPa}$

$\rightarrow 0 \mathrm{kPa} \rightarrow-100 \mathrm{kPa} \rightarrow-200 \mathrm{kPa}=300 \mathrm{kPa} \rightarrow-400 \mathrm{kPa} \rightarrow-500 \mathrm{kPa}$

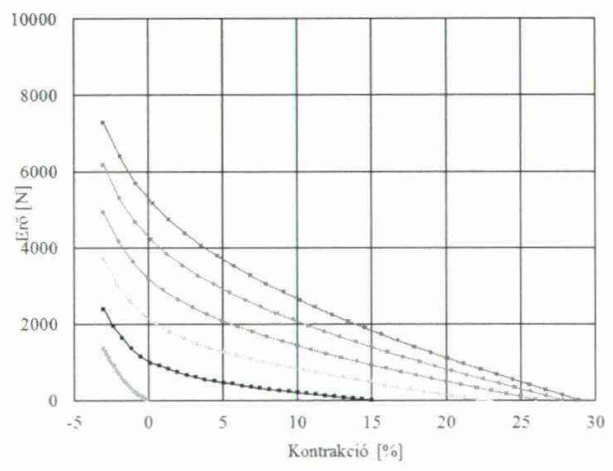

Forrás: A szerzők saját szerkesztése.

Valamennyi erö-kontrakció görbét harminc mérési pont alapján határoztuk meg, amit az alkalmazott inkrementális enkóder (LINIMIK MSA 320) 0,01 mm-es felbontása tett lehetővé. Ahogy a diagramokból is kitünik, az átmérő növekedésével a PMI által kifejtett erö is növekszik, továbbá az is látható, hogy azonos átmérö esetén a hosszúság is befolyással van az erőre. 


\section{4. Összegzés}

E munkánkban egy pneumatikus mesterséges izmok vizsgálatára kifejlesztett mérőberendezés tesztelését végeztük el különböző átmérőjü és hosszúsású izmokkal. Laboratóriumi kísérletekkel igazoltuk, hogy e többfunkciós tesztberendezés alkalmas a PMI-k legfontosabb jellemzőjének, az erő-kontrakció jelleggörbék felvételére, ami nélkülözhetetlen a PMI-kre általunk kidolgozott, statikus eröfüggvényen alapuló dinamikus modell további elemzéséhez és továbbfejlesztéséhez (Sárosi, 2015b).

\section{Irodalomjegyzék}

Balara M. (2013): The Upgrade Methods of the Pneumatic Actuator Operation Ability. Applied Mechanics and Materials. 308, 63-68.

Daerden F., Lefeber D. (2002): Pneumatic Artificial Muscles: Actuator for Robotics and Automation. European Journal of Mechanical and Environmental Engineering. 47, 10-21.

Festo (2015): Fluidic muscle DMSP/MAS. Termékkatalógus. 39.

Pitel J., Tothova M., Vagaská A., Janáčová D., Liška O. (2014): Torque Characteristics of Pneumatic Muscle Actuator with Eccentric Pulley. International Journal of Mechanics. 8, 276281.

Ramasary R., Juhari M. R., Mamat M. R., Yaacob S., Mohd Nasir N. F., Sugisaka M. (2005): An Application of Finite Modelling to Pneumatic Artificial Muscle. American Journal of Applied Sciences, 2:(11), 1504-1508.

Sárosi J. (2013): Pneumatikus mesterséges izmok mũködésének statikus és dinamikus madellezése, nagypontosságú pozicionálása. Doktori $(\mathrm{PhD})$ értekezés. SZIE Müszaki Tudományi Doktori Iskola, Gödöllö, 161.

Sárosi J., Csikós S., Szabó Z., Bálint Á., Gergely A., Dobó F. (2015): Pneumatikus mésterséges izom által müködtetett rehabilitációs eszközök tervezése és kivitelezése. Jelenkori Társadalmi és Gazdasági Folyamatok, 10:(2), 131-139.

Sárosi J., Bíró I., Németh J. Cveticanin L. (2015): Dynamic Modelling of a Pneumatic Muscle Actuator with Two-direction Motion. Mechanism and Machine Theory. 85, 25-34. 